\title{
Soviet Libraries
}

This account is based upon a talk given before the Conference of Eastern College Librarians at Columbia University on January 29, 1944.

$\mathrm{T}$ HE OUTSTANDING FACT about the library facilities in the Soviet Union is their amazing growth. The available figures-they relate to the period of the second and third five-year plans-are eloquent. In 1934 there were some I 16,000 libraries containing about 299,000,000 books; in I939 24I,000 libraries with 442,000,000 volumes were in existence. These data are cited in a book written by the dean of Russian librarians, Mme. L. B. Havkina, and published in Moscow in 1943 under the title Svodnye Katalogi (union catalogs). Incidentally, it is one of the few Russian books on a library subject which has reached the author's desk since the beginning of the war.

The figures for 1939 are those of Tzentralnoe upravlenie narodno-khozyaistvennovo ucheta (the central bureau of statistics). The earlier figures, too, are official. They are based on the findings of the detailed library census taken on Oct. I, 1934, in accordance with a decree issued by the Central Executive Committee of the Soviets, the highest administrative organ of the union. The census covered not only the size of the collections, the number of readers and of volumes used, but also personnel, salaries, area of library buildings, and other relevant matters. In good time this mass of statistics was duly tabulated and published in the form of two substantial volumes. ${ }^{1}$ What swells the totals given above is the fact that they include small libraries, for instance, those attached to kindergartens and elementary schools. It should be noted, however, that for I934 Mme. Havkina omitted some ninety thousand kindergarten and school libraries which at that time did not furnish information regarding the size of their collections, but it is not clear whether she followed the same procedure in computing the figures for 1939.

The 1934 census was carried out under the supervision of the state planning commission by the commissariats of education of the constituent Soviet republics and by the Supreme Soviet of the Trade Unions. The participation of the latter body was due to the fact that a number of libraries, for example those attached to trade schools, are under its jurisdiction. Other libraries, according to their character, are controlled by the various commissariats, but the largest number are subject to the authority of the commissariats of education, of which there is one in each of the autonomous republics that make up the union. It goes without saying that library service is furnished exclusively by the state and that, like the schools, the press, the movies, and the radio, libraries are under strict government control.

The distinction between popular and

1 Tzentralnoe upravlenie narodno-khozyaïstvennovo ucheta. Vsesoyuznaya bibliotechnaya perepis l-go oktyabrya 1934. g. Moscow, I936. 
special or research libraries obtains in the U.S.S.R. as elsewhere. But in Soviet terminology the former institutions are known as mass libraries. These may serve a region or a district or be urban or rural; they may exist independently or function in connection with a club, an industrial plant, a lumberjacks' cooperative, a state farm, a tractor station. They are largely financed from local funds though certain items of library equipment may also figure on the budgets of the republics. Local funds also support most of the school and children's libraries but only some of the specialized reference libraries attached to factories, "trusts," financial institutions, planning commissions, and the innumerable bureaus that compose the administrative machinery of the cooperatives, the trade unions, the Communist Party, and the government.

\section{State Public Libraries}

Let us look a little more carefully at three types of Soviet libraries that are closest to the interests of college librarians. The so-called state public libraries come first. These are the great central book depositories of the union. Among them, to begin with, is the institution sacred to the father of Soviet Russia, the Lenin Public Library of Moscow. It is the national library of the Soviet Union. Prior to the German invasion its new building, reputed to be the biggest library structure in Europe, was nearing completion. It is largely a Soviet creation, developed since the revolution from a nucleus that was the prerevolutionary Rumyantzov library, not a very old, extensive, or distinguished collection, as book collections go in Russia. According to the census of 1934, the number of books in the Lenin library stood at nearly nine and a half million, of which, however, only about half were duly processed. An official Moscow statistical handbook ${ }^{2}$ credits the library with nine and a quarter million books as of 1937, without drawing any distinction between processed and unprocessed volumes. The total includes, no doubt, a huge reserve and duplicate fund. Even so, the growth of this collection has been phenomenal. It must have absorbed some of those vast stocks of printed matter that accumulated in the early years of the revolution, owing to the nationalization of private libraries and of the libraries of institutions that had been liquidated.

Another state public library is the former Imperial Library of St. Petersburg. Some years after the revolution it was renamed for Saltykov-Shchedrin, a celebrated satirist of the old regime, and on the occasion of its one hundred and twenty-fifth anniversary, which occurred in 1939, it was decorated with the Order of the Workers' Red Banner. As a result, it is officially styled the SaltykovShchedrin State Public Workers' Red Banner Library, if I may offer a rather lumbering translation. When it first opened its doors, two years after $\mathrm{Na}$ poleon invaded the country, it had on its shelves exactly five volumes in Russian, in addition to some 250,000 volumes in the Western languages seized in Warsaw by order of Empress Catherine after the suppression of the Kościuszko insurrection. The books were divided into seven classes, for does it not say in the Bible, "And wisdom hath hewn out her seven pillars"? Some few changes have occurred since then in the library. To make a long story short, in 1937 it was officially reported to house over eight and a half million books, ${ }^{3}$ although three years earlier

2 Sotzialisticheskoe straitelstov S.S.S.R. (19331938. Moscow, 1939, p. I29.) 
it was credited with only $6,150,000$ units and a duplicate fund of one million units ( $\mathrm{I}$ am, of course, referring to the census of 1934). A third Russian source credits it, as of 1939, with nearly ten million books, including a duplicate fund of two and a half million units. It is not my ambition to settle the question as to whether the Lenin library of Moscow or the public library of Leningrad has the larger holdings, and consequently which of the two has the distinction of being the largest library in the world. Whatever the exact size of its holdings may be, the Leningrad Public Library, with its vast and systematic accumulations of literature, native and foreign, with its many special collections and with its priceless assemblage of manuscripts, is one of the world's really great treasure houses of culture. Its official - status is that of the national library of the Russian member of the Soviet federation.

\section{Libraries of the Republics}

Each of the other constituent republics, too, presumably has its central library, at least in the making. The national library of the Ukrainian Republic, which is also the Library of the Ukrainian Academy of Sciences, has been located in Kiev. With its seven million volumes, of which, according to the census of 1934 , five and a quarter million were processed, it is an institution of more than local significance. The other republican libraries, if I may phrase it that way, like that of White Russia at Minsk, are perhaps only of regional importance. There were thirteen state public libraries in 1934 and the same number in 1939.

The Leningrad Public Library caters both to the general public and to students and has a children's library in an annex. The activities of the other great central libraries are similarly varied. The abundant resources of these institutions eminently fit them to act as research libraries also.

\section{Research Libraries}

In addition, there are research libraries functioning exclusively as such and so designated. Some of them have a broad scope. Such is, above all, the library of the Academy of Sciences in Leningrad. Although it cannot boast of more than a paltry four million volumes, its collections, which have been accumulating since the time of Peter the Great, place it among the world's major libraries. The very fine library of the Academy for the History of Material Culture and the distinguished collections of books and manuscripts available at the Historical Museum in Moscow and in the recently opened historical library in the same city, cover a rather wide field. Then too there are highly specialized research libraries. One can instance, among others, those attached to the Leningrad Diesel Institute, to the Institute of Aerial Photography in the same city, to the Moscow Institute of Horse-Breeding, and to the Institute of Graphic Statistics.

Finally there is the Soviet equivalent of our college libraries. Where we speak of colleges and universities, the Russians speak of vuzy or institutions of higher learning. As a rule, these do not offer courses in the liberal arts. By the time a student enters a $v u z$, he is assumed to have completed his liberal education. Some of these Soviet institutions still bear the glamorous name of university. But a Soviet university is very different from the traditional universitas, a school offering instruction in all the branches of higher learning. The Soviet university generally limits itself to the exact sciences. 
One or two also have a department of history. Higher education is carried on largely in special schools. The general tendency there is to bring theory closer to practice, to concentrate on what is immediately useful, to make instruction subservient to the social purposes of the new dispensation. It is not surprising to find a trend to overspecialization. The Leningrad institutions of higher learning include a college for the preparation of Communist Party cadres, an institute of automobile roads, and a school of restaurant engineering; among the Moscow vuzy there are a peat college and a school offering instruction in the art and science of bread-baking. Incidentally, this latter school boasts a library of forty thousand volumes.

That the equipment of each institution of higher learning includes a library or a group of libraries may be taken for granted. Many of them offer facilities for research in special fields. The drastic reorganization of the old universities and professional schools that has taken place since the revolution meant a similar reorganization of the libraries attached to them. Collections were broken up, combined, rearranged, shifted from place to place. In the process they must have suffered somewhat. On the other hand, it is certain that both the number of college libraries and their resources have greatly increased since the coming of the new order. In 1934 there existed 2395 research libraries with thirty-five million volumes and II 39 college libraries with forty-eight million volumes; by 1939 the number of libraries had dropped respectively to 1557 and 663 (L. B. Havkina. Svodnye katalogi, p. 10). Since their holdings had grown during that interval, consolidation must have taken place as a reaction against overspecialization. The maintenance of the three types of libraries dealt with above figures partly in the budget of the union, partly in the budgets of the individual republics.

\section{"Obligatory Copies"}

Some of the principal libraries in the union are provided with the current output of the Soviet presses, which is enormous, by means of an arrangement involving the so-called "obligatory copy." Every printing press is under legal obligation to deliver to the Union Book Chamber, free of charge, a number of copies of every publication produced. The chamber is a combination of a copyright depository and a bibliographical institute. Here each item is registered and carefully described on a standard catalog card, which is printed for the use of libraries and is eventually inserted into an issue of the weekly Knizhnaya Letopis, the official bibliography of the union. One or two of the obligatory copies are retained by the chamber, the rest are distributed among certain libraries specified by law. The library of the Academy of Sciences gets three, while the Lenin library and the Leningrad Public Library receive two obligatory copies of every book, serial, and important newspaper, and these two libraries also get one copy of all the other newspapers issued within the union. Certain special libraries are also supplied with one copy of every publication in their respective fields. Until recently the number of obligatory copies varied from forty-five for books, periodicals, and maps, to two for mimeographed institutional material. A decree of the Soviet of the People's Commissars dated Nov. 10, 1939, reduced the number of copies to twentyfive for more important publications and 
to four for minor and ephemeral items. An official ordinance of May 9, I940, put every publishing agency under obligation to deliver to O.G.I.Z. (the central state publishing house) I 50 copies, of those first printed, to be sold either at a discount or at cost price to a specified group of libraries. A number of free obligatory copies in the languages of the ethnic minorities of the union are also distributed among the local libraries. ${ }^{4}$

\section{Distribution of Libraries}

The 1934 library census, Mme. Havkina points out, has revealed the uneven distribution of library facilities in the union. This is a rather obvious fact and one rooted in the whole history of the vast country. But the hinterland is waking up. A demand for books is growing in the remotest sections. Hence, the cry for an interlibrary loan system on a national scale. This, it is argued, means a fuller and fairer utilization of existing resources. By 1933 the Central Committee of the Communist Party was won over to the idea. And so the following year the Commissariat of Education of the R.S.F.S.R. decreed the practice. Simultaneously the postal authorities were instructed to accept free of charge parcels of books going from library to library. Although this postal regulation was rescinded four years later, interlibrary loan enjoys a considerable vogue.

Under the circumstances, the problem of union catalogs begins to loom large. Without such catalogs, it is argued, interlibrary loaning cannot be carried on efficiently. In fact, Mme. Havkina's latest book is a plea for them, a history and survey of those now existing, and a man-

\footnotetext{
4 Godkevich, M. A. "Sovetskoe zakonodatelstvo ob obyazatelnom ekzemplyare," Sovetskoya bibliografiya, 1940, I.
}

ual on the technique of compiling them.

In this work Mme. Havkina would link the construction of union catalogs with another bibliographical project now under way in Russia. Since 1927 the book chamber has been printing cards for all Soviet publications. We now learn that the Leningrad Public Library has printed cards, about 125,000 of them, for all titles issued from 1917 to 1926 . The material is thus ready for the publication of a complete repertory of the Soviet book, about eight hundred thousand titles in all, and the book chamber has been instructed to carry out the project. In the meantime, the Leningrad Public Library is to go on compiling cards for Russian publications covering the period from 1725 to 1917 , estimated to run to about 550,000 titles. As the output of the Russian presses from the beginning of printing in 1564 to the death of Peter the Great in 1725 does not exceed a few hundred titles, a complete register of the Russian book, which has long been the dearest wish of Russian bookmen, is no longer a dream. Mme. Havkina suggests that the proof copy of the cards should be circulated at least among the major libraries, thus enabling them to make additions to the list and to indicate location of copies. She envisages a network of regional union catalogs, eventually to be combined into a master catalog for the entire country. Of course, all these projects must remain in abeyance while the war goes on.

\section{Libraries in the War}

And what has been happening to Soviet libraries while the war has been going on? It is hard to answer this question. The world knows that the Russians are fighting with a wholeheartedness that gives a new meaning to the hackneyed phrase, "total 
war." Naturally, library resources, like everything else, are mobilized to help the war effort. It is reported that the libraries of Moscow functioned normally even during the critical days when the Germans were at the gates of the capital. The Lenin library is now engaged in making a most comprehensive collection of materials relating to the war. I have seen a statement to the effect that three and a half million books have been removed from its shelves to a place of safety. Many of the more precious volumes belonging to the Leningrad Public Library have also been evacuated, while its catalogs, occupying an area of eight thousand square feet, were moved to the cellar of the building. The way the staff of this great library carried on without a day's stoppage under indescribable hardships throughout a long siege is part of the epic of Leningrad. I am glad to be able to report that while neighboring buildings have been gutted, the Leningrad Public Library has remained unscathed by the bombing. Apparently the library of the academy has also escaped damage from the onslaughts of war.

There is no question but that in the occupied regions the libraries suffered heavily from wanton destruction and looting. Detailed information on the subject must naturally wait upon the end of hostilities. Already, however, certain facts have come to light. The library of Orel was burned. The collections of the central library of Minsk have been either removed to Germany or destroyed. The library of the University of Kiev was blown up. A similar fate has befallen the libraries of many White Russian and Ukrainian cities. According to an authoritative statement in Izvestiya for Dec. 31 , 1943, in the region of Kharkov the Germans demolished I 780 clubs, village reading-rooms, and libraries out of a total of I8oo. About four million volumes have been either destroyed or removed from Kiev alone. Only a part of the collections of the great Korolenko library of Kharkov, next in importance only to the Ukrainian National Library of Kiev, has been preserved.

From occasional notices in the press one gains the impression that the restoration of devastated libraries is carried out without delay as part of reconstruction activities. In a postscript to her book, Mme. Havkina indicates that she has laid before the proper authorities a plan for the formation of a state fund for the restoration of destroyed libraries. The books to be contributed to the fund should come from the public, the publishers, the Soviet-libraries, as well as from British and American libraries, the latter perhaps on an exchange basis. It is not known if the fund has actually been established, but it appears from a recent issue of the Information Bulletin of the Soviet Embassy in Washington that the Lenin library has released one hundred thousand volumes for the libraries that are being restored in the occupied regions. 